
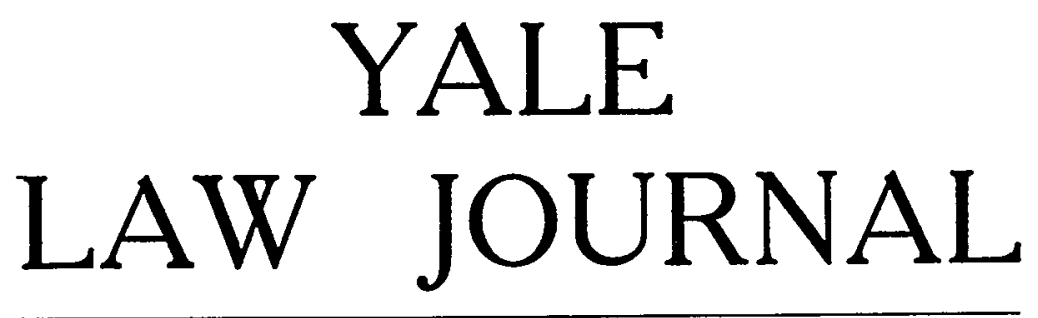

\begin{tabular}{lll}
\hline \hline Vol. XVIII & FEBRUARY: 1909. & No. 4 \\
\hline \hline
\end{tabular}

\title{
THE HISTORICAL POSITION OF THE RHODIAN LAW
}

The Rhodian Maritime Law has been spoken of by many legal writers. I quote as a sample, the words of Park, in the introduction to his work on Marine Insurance, as follows:

"The Rhodians were the first legislators of the sea and promulgated a system of marine jurisprudence, to which even the Romans themselves paid the greatest deference and respect, and which they adopted as the guide of their conduct in naval affairs. * * * * The time at which these laws were compiled is not precisely ascertained, but we may reasonably suppose it was about the time when the Rhodians first obtained the sovereignty of the seas, which was 916 years before the era of Christianity."

I desire in this paper to show (first) that the above statements (though accompanied, as they are, by sinilar statements of many authors) have no sufficient historical foundation, and that all that can be accurately saicl to be known about the Rhodian Law is that there is one sentence of it extant and only one, and that whether that was a sentence from a code, a juclicial decision, or a mercantile usage, cannot be known; and (second) that there is no proof that any other sentence of Rhodian Law was ever aclopted into the law of Rome.

The statements as to the Rhodian Law and its acloption by the Romans, made by several authors similar to those which are quoted above, seem to be based upon a book bearing the title of Rhodian Law, or Nautical Law of the Rhodians, which was first put in print in the year 1596, and of which there are several earlier manuscripts, one of which bears the date of 1478 .

If that book were authentic, the claim that Rhodes had a maritime code would have in it a sufficient support. But as to its 
authenticity there is an absolute contradiction among writers. And, after verifying all references, and examining all authorities whicb I have been able to reach, I have no hesitation in agreeing with the view of those who have declared that that work is spurious.

As to its being a Statute,- - Code drawn up by the Rhodians, there is not, as far as I can see, a particle of evidence that it is such. It does not even pretend to be such. It is composed of three parts, or rather of a Prologue and two parts, the whole bearing the title, Fragments Pertaining to Nautical Affairs Which Are Commonly Called the Nautical Law of the Rhodians. "Commonly called!" The very title makes no claim to authenticity.

The first of these two parts bears the'title, Heads of the Nautical Law, followed by nineteen different subjects, then the title, Nautical Lard, followed by nineteen short articles on those subjects.

The second of these two parts bears the title, Heads of the Nautical Law of the Rhodians, which heads follow, fifty-one in number, after which comes the title, Maritime Laze of the Rhodians Selected Out of the Eleventh Book of the Digests, followed by fifty-one sections relating to those heads.

It does not say what Digests are referred to. But it is to be presumed that the Digests of Justinian were intended. At any rate, no other Digests are known from which the selection could have been made, and on this assumption we meet at once a most suspicious difficulty. For the Eleventh Book of the Digests of Justinian does not contain one word of what this title declares was selected from it, but treats of entirely different subjects.

Pardessus, who has printed this publication in his Loix Maritimes, says, that there are two ancient manuscripts of this socalled Rhodian Law, in which it is stated that these fragments are selected not out of the Eleventh, but out of the Fourteenth Book of the Digests, which is in fact, the Book of the Digests in which the Rhodian Law is mentioned.

But, whether we are to read this title as stating that the matter was selected out of the Eleventh or the Fourteenth Book of the Digests of Justinian, how could any one, who considered matters carefully, think that a collection of sentences, which on its face is stated to have been taken out of the Digests of the Emperor Justinian, was properly to be called a collection of laws passed by Rhodian authority,-a Code framed by Rhodian legislators, unless 
the Digests stated that those provisions were provisions of Rhodian Law? Now the Digests made no such statement, but a contrary one.

Besides this mention of Rhodian Law in the title of the second part of the work, it is also mentioned in one article of the first part, but in a way entirely inconsistent with any Rhodian character of the work.

For that article says, as to each of two different provisions, that according to the Rhodian Law, such is the rule.

This mention of the Rhodian Law is of itself sufficient to show that the compilation is not a compilation of Rhodian Laws. We may search all the Cocles which have afflicted New York lawyers, and we shall nowhere find such a sentence as that this provision or that is so, according to the Neze York Code. A Statute of another State might use such language, but its use would prove that the Statute was not a Statute of New York. And so those words, "according to Rhodian Law" in this compilation, prove that it is not a Rhodian compilation.

We find, therefore, in the first part of this so-called Rhodian Law, only such a mention of Rhodian Law as is ttterly inconsistent with a Rhodian character. In the second part, we find a mention of Rhodian Law only in the title, which title also states the source of the provisions of that part to be, not any Rhodlian authority, but the Digests, presumably of Justinian; and we also find that that statement is not borne out by the facts, because these provisions are not to be found in the Eleventh Book of the Digests; nor, as they are given, are they to be found anywhere in the Digests.

The Prologue of this work is as follows:

"Nautical law of the Rhodians, which the most sacred Emperors, Tiberius, Hadrian, Antoninus, Pertinax, Lucius Septimius Severus, most august forever, have decreed.

"Tiberius Caesar Augustus, pontifex-maximus, in the thirtysecond year of his tribunitial power.

"When sailors, shipmasters and merchants demanded of me that whatever things happen on the sea should come into contribution, Nero answering, said, 'Greatest, Wisest, Most Serene Tiberius Caesar, truly I think it is in no way necessary that I should approve of the things which are proposed by your Majesty. Send to Rhodes, that diligent inquiry may be made about the business of seafaring men, and merchants, and passengers, about taking cargo in ships, about maritime partnerships, about purchases and sales of vessels, and hire of shipwrights, and deposits of gold and silver and different things.' 
"When Tiberius had included all these things in a decree and had signed it, he delivered it to Antoninus, most illustrious Consul, and to other consular men, who advised him in that fortunate Rome, the crown of cities, Laurus and Agrippinus being most illustrious Consuls.

"By those same men these things were also brought before that greatest emperor, Vespasian, and, when he had set his signature to them in a very full senate, Ulpius Trajan with the most illustrious senate, decreed this law of the Rhodians."

Taking this Prologtre as it stands, it is manifest that we have no Code adopted by Rhodian authority, but a setting forth of what was adopted by Roman authority, after an inquiry at Rhodes, not as to the action of legislators, or even as to the views of jurists, but about the business of seafaring men, and merchants, and carriers, etc. Usages and customs, not laws, are declared to be the stubject of this supposed inquiry at Rhodes.

It is plain that the composer of this Prologue was intending to attach a force of Roman imperial sanction to the two following parts of his work. But he has clone this in such a bungling way that his deceit is manifest. For he states, first, that this alleged inquiry at Rhodes was orclered by the Emperor Tiberius in the thirty-second year of his Tribuneship, and his decree was given to the Consul Antoninus.

Now Tiberius only reigned twenty-three years, and only reached the twelfth year of his Tribuneship. And there was no such consul as Antoninus or Laurus, or Agrippinus, in his reign.

Then the Prologue proceeds to state that these things were brought before the Emperor Vespasian by the same distinguished men to whom Tiberius had committed them. But Tiberius died A.D. 37 , and Vespasian began to reign in the year 70 A.D. So that it must have taken these men at least thirty-three years to go from Rome to Rhodes and make their inquiry and return, unless their report remained for many years without being acted upon. And the action on their report, which is stated to have "decreed this law of the Rhodians," is said to have been taken first by Vespasian, and then repeated by Trajan, who began his reign twenty-eight years later.

Not content with these two emperors, the author of the Prologue, in the title, declared that this law was also "decreed" by Hadrian, who began to reign A.D. 117, by Antoninus, who began to reign A.D. I28, and by Pertinax, and Severus, who reigned from A.D. 193 to 198.

So we have here the extraordinary statement that the result 
of an inquiry under imperial authority, which it took thirtythree years to make, was decreed by Imperial Edict, which made it law, six times during one hundred and sixty years, by six different emperors. This statement of itself, is manifestly incredible. The laws decreed by a Roman Emperor did not pass out of existence, so as to require re-enactment by his successors. And when we find that these provisions of law, thus stated to have been so frequently decreed, contain provisions which are in direct opposition to the principle which we know that the Roman Law did adopt from the Rhodian Law, this excessive claim to imperial sanction becomes a manifest badge of deceit.

I have not found a particle of historical authority for the statement that Tiberius organized such a commission of inquiry, or that any of these emperors macle such a decree as is here stated.

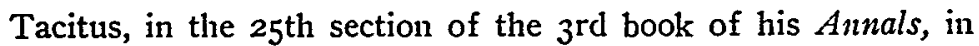
which he gives a history of the reign of Tiberius, having mentioned that under that reign many men were overthrown by laws, says, "This gives me occasion to speak more at large of the beginnings of laws, and in what ways we are come to such an infinite multitude and variety of them." He proceeds to mention the laws of Crete, of Sparta, and of Athens, and speaks of the composing of the law of the twelve tables, after the laws which were excellent everywhere had been brought together. But not one word does he say of the laws of the Rhodians, or of any mission to Rhodes under Tiberius, or of any adoption of Rhodian Laws by him, or by Vespasian, or Hadrian. Tacitus was a lawyer, and such important events could not have been unknown to him. And if they had been known to him, they could not have been omitted when he was speaking of the beginnings of Roman Law and the causes of their variety.

Moreover, in the second book of the Digests there is given a historical sketch of the origin and growth of the laws of Rome. Mention is made in it of the fact that, after the expulsion of the Kings, men were sent by public authority to Greece, to make inquiry about the Grecian Laws, from whose labors resulted the law of the twelve tables. But there is no mention of this supposed similar inquiry at Rhodes, although purporting to have been made in much later years and to have been acted upon by so many emperors.

And the fact that in the Digests of Justinian no such inquiry and no such decree is cited or allucled to, and that, where the 
Rhodian Law is referred to in the Digests, the authority given for it is not an Imperial Decree at all, is to my mind conclusive evidence that no such authority existed. I think that the known authors of the Digests are more to be relied on than the unknown author of this alleged Rhodian Law and its Prologue. And I do not believe that he had knowledge of imperial edicts of Vespasian, or Trajan, or Hadrian, or Pertinax, or Severus, which were unknown to Tacitus, and also were unknown to Tribonian and his associates, the authors of the Digests, whose labors were hundreds of years nearer to the times of those Emperors than was the life of the unknown author of this alleged Rhodian Law.

Moreover, although this Rhodian Law claims authority from six Latin Roman Emperors, it was written in Greek, and Greek of a late date, and so impure that the Hollander, Bynkershoeck, sneeringly asks, "What Rhodian ever wrote such Greek?" And no original in Latin, from which it could have been translated, is found. The Latin copies of it are all translations from the Greek.

There is another fact which is a still farther demonstration that this alleged Rhodian Law came into existence long after all the emperors, whose authority was thus claimed for it, had passed away. The Fourteenth Article of it provides that the master of a ship shall take an oath on the Gospels in one contingency.

No heathen Emperor ever established such a regulation. This article is conclusive proof that instead of this alleged Rhodian Code having been promulgated goo years before the Christian Era, shortly after the reign of Solomon in Jerusalem, and decreed by Roman Emperors, it was the production of a time when the oath upon the Gospels was the usual form of a binding oath, and long after the death of those Emperors.

There is still another fact in reference to this alleged Rhodian Code, which is also conclusive proof against its authenticity. The fragment of the Rhodian Law, which is inserted in the Digests, states as the principle to be applied in cases of jettison, i. e., of the throwing overboard of cargo to lighten the ship, that "what has been sacrificed for the good of all should be made up by the contribution of all." But two articles of this alleged Rhodian Code make no requirement of a sacrifice for the common good. They throw overboard-they make a jettison of that distinctively Rhodian principle which lies at the foundation of the law of 
general average. And a compilation which does that cannot be Rhodian.

The learned Hollander, Bynkershoeck, says, "We fitly wholly reject that Rhodian Law, which some hungry little Greek or other fabricated."

And beside this may be placed this sentence of another Hollander, Heineccius, "Whoever thrust forth into light those nautical laws, made a deception for learned men; and it is a wonderful thing that Godefroy" (a learned author who wrote in the Seventeenth Century on the Empire of the Sea) "who elsewhere was as keen-scented as a rhinoceros, did not smell it."

It is curious to remark that this attempt to give currency and authority to these so-called Rhodian Laws by attaching to them a fabricated statement that they had been adopted as laws by so many Roman Emperors, is not the only instance of the kind.

A similar document was prefixed to the Consolato del Mare. It purported to set forth seventeen different adoptions of the Consolato as law by various sovereigns and nobles, between the year II7O and the year I270.

Pardessus examined this document with his usual perspicacity and satisfied himself that the whole thing was a fabrication, but I have not room for his demonstration.

Now let us see what authentic information as to the maritime law of the Rhodians we can really find.

The great erudition of Pardessus is shown by the numerous authorities, Greek and Roman, which he has cited throughout his Loix Maritimes. He has found two, and only two, references to Rhodian laws among classic authors. And, although Azuni, in his History of the Maritime Law of Europe, speaks of "the importance of the Rhodian Laws, so often cited and mentioned in the Roman Law," he cites no other instances than those same two. Nor does any one of all the authors who have spoken of the indebtedness of Rome to Rhodes, for her maritime law, whose works I have been able to examine, mention any other than these two. One of these is Cicero. In Cicero's work on Oratorical Invention, is the following:

"Necessity is alleged when the accused was forbidden to do what he has done under compulsion. For example: There is a law among the Rhodians that if any beaked ship" (i. e., ship fitted for fighting) "shall be found in any port, it shall be confiscated. When there was a very great tempest, the force of the 
wind, against the will of the sailors, drove a ship into a port of the Rhodians."

And then, says Cicero, the question is whether the ship shall be confiscated because found in the port, although she was driven in by force of necessity.

The other authority is Strabo, who says that some of the dockyards in Rhodes were kept private and that if any persons should be found inspecting them or to have entered them they would be punished with death.

The maritime power of Rhodes is stated to have been prominent during the three or four centuries preceding the Christian Era, and this, therefore, would naturally be the period during which the Rhodlian Maritime Law, if any such existed, would have taken form and substance. But these two references by Cicero and Strabo, both made not far from the time of the Christian Era, seem to be the only references to Rhodian Law which either Greek or Roman literature can furnish us.

If we would find any authentic reference to any Rhodian Law of the Sea, we must come down to a period long after Rhodian supremacy at sea had come to an end. We must follow the example of the unknown writer who put forth his alleged "Nautical Law of the Rhodians, selected out of the Eleventh Book of the Digests." We must search not the Eleventh, indeed, but the Fourteenth Book of the Digests of Justinian put forth by his imperial authority about A.D. 533. In that book and in a book referred to by it, we shall find all the knowledge which is left to us as to what was at any time the law maritime of the Rhodians.

One of the titles of the Fourteenth Book of the Digests is headed as follows: De lege Rhodia de Jactu-Of the Rhodian Lawe of Jettison.

From this we learn that Tribonian and his associates who, by the authority of Justinian, prepared the Digests or Pandects, recognized the fact that there was Rhodian Law on the stibject of jettison. And we may safely accept their authority for that fact.

This title of the Fourteenth Book of the Digests is divided into ten articles. The first of them reads as follows:

"By the Rhodian Law it is provided that if, for the sake of lightening a ship, a jettison of goods has been made, what has been given for all shall be made up by the contribution of all." 
Here, then, we have a positive statement as to one provision of the Rhodian Law. But to whom is this statement to be attributed?

In the second preface in confirmation of the Digests, which is addressed "to the Senate and to all peoples," the Emperor Justinian said:

"We have so much respect for antiquity that we do not wish that the names of the jurisconsults, whose works have been employed in our collection, should be buried in oblivion. We have put at the beginning of every law of the Digest the name of its author."

Looking, then, to the beginning of that statement of Rhodian Law in the Digests, for its authority, we find that the authority given is not a Rhodian Code, or a Rhodian Statute, or a Rhodian author. The authority put at the beginning of this law is the Second Book of the Sentences of Paulus.

Paulus was a Roman lawyer who wrote five books of Sentences for his son. They are still extant. And in the Second Book, there is a division headed, Ad legem Rhodian, On the Rhodian Larv.

This division contains five articles, the first of which is the words quoted above from the Digests, with the exception of the first clause, "By the Rhodian Law, it is provided." So that that clause appears to have been a statement, not made by Paulus, but inserted by the authors of the Digests, that that principle was a provision of the Rhodian Law of Jettison.

That first article is the only one which can, with any regard to accuracy, be claimed to be Rhodian Law .

Azuni, in his History of the Maritime Laze of Europc, says that Tribonian, the author of the Digests, has "extracted from the Rhodian Law ten laws."

There are, indeed, ten different articles divided into sections in that title of the Fourteenth Book of the Digests. But for every one of them the authority of a Roman jurisconsult is given by name. And the first of them is the only one in which any statement, as to what Rhodian Law was, is made. That article, indeed, is most important, as stating the principle of general average which was laid down in the Rhodian Law as applicable to the case of jettison. It was important enough to have entirely justified the compilers of the Digests in prefixing to that title, which was a collection of articles applying that principle to different cases, the statement that that title was "Concerning the 
Rhodian Law of jettison." But I fail to see any foundation for the suggestion that the other articles were taken from the Rhodian Law, in the face of the fact that for each one of them a Roman authority is by name assigned.

And even Azuni himself on a later page says that these articles are "nothing but the decisions of certain Roman lawyers."

The third section of the second article of that title of the Fourteenth Book of the Digests (which is stated to have been taken from a work of Paulus on The Edict), reads as follows:

"If the ship is ransomed from pirates, Servitus, Ofilius, Labeo, say that all should contribute. But, as to what robbers have carried away, they say that its owner must lose it. Nor is there any contribution for him who has ransomed his goods."

Servius, Ofilius and Labeo were jurisconsults in Rome, who lived not far from the Christian Era, and it thus appears that they all had considered the subject of the maritime law of contribution with reference to the case of piracy and robbery, and had given opinions upon it as a matter of Roman Law, and without reference, so far as we know, to any Rhodian Law.

The inference would seem to be a fair one, that, even if the principle of contribution were first stated in the Rhodian Law, in its application to the case of cargo thrown overboard to lighten the ship, yet as early as the Christian Era the question of how to apply that principle to the multifarious accidents of the sea had been so considered and discussed by Roman jurisconsults, as to establish the fact that there was at that date a body of Roman Law on the subject. How far it agreed with the Rhodian Law except in its acceptance of that foundation principle it is impossible to tell.

And, as there is nothing in any other book of the Digests as to the Rhodian Law of the Sea, if I am asked the question, What is there extant of the Rhodian Law of the Sea? I must answer that, speaking with strict accuracy, we have the statement of the authors of the Digests of Justinian that it was provided by the Rhodian Law that "if for the sake of lightening a ship a jettison of goods has been made, what has been given for all shall be made up by the contribution of all." And we have nothing else.

And we cannot tell whether this little piece of Rhodian wreckage, thrown upon the shores of time, was a fragment of a statute or a decision of a court of law, or the result of long continued 
usage. The word which is used in the title of the article in the Fourteenth Book of the Digests is "lex," which is the same word used by Cicero when he says, "There is not one law (lex) at Rome and another at Athens, one law to-day and another afterwards." It is appropriate, whether it referred to statute, decision, usage or general principle.

All the statements of all the authors who have enlarged upon the "maritime Code" of the Rhodians-their "system of marine jurisprudence," are therefore shown, on close examination, to be either statements of those who accepted that fabrication of the "hungry little Greek" as genuine, or repetitions of those statements by others who followed those earlier statements, without noticing that the discovery that it was a fabrication had destroyed all foundation for such statements.

It is open, doubtless, to anyone to say, "It is my opinion that among a people, who had formulated so clear a statement of principle as that statement as to the law of jettison, there must have been a stating of other principles as to other questions, which would naturally have arisen among a maritime people." As to that, everyone is entitled to his own opinion, and to state it as such. But the positive statement as an undoubted fact, that such a Code of Rhodian Laws did exist, and is entitled to the respect due to such great antiquity, is a statement which has no sufficient historical support to justify it.

The consideration of my second question, "What authority is there for the statement that Rome was indebted to Rhodes for her maritime law, and adopted the Rhodian maritime law, as her own?" brings me to the examination of another article in the same title of the Fourteenth Book of the Digests, the famous Ninth Article, which mentions Rhodian Law. It gives us no additional knowledge as to what any provision of Rhodian Law was, but it does bear on the relative positions and importance of Rhodian and Roman Law.

That article is an anecdote, containing a statement about the Rhodian Law, as follows:

"The petition of Eudaemon of Nicomedia to the Emperor Antoninus. 'Lord and Emperor Antoninus! making shipwreck in Italy, we have been plundered by tax gatherers inhabiting the islands of the Cyclades.' Antoninus answeres Eudaemon, 'I, indeed, am lord of the world, but the law lord of the sea. Let it be judged by the Rhodian Law, prescribed concerning nautical matters, so far as no one of our laws is opposed.'

"The same thing has the Divine Augustus decided." 
The authority given for this anecdote in the Digests, is Volusius Moecianus, of whom Pardessus says, that he was a lawyer who appears to have lived under the Antonines, as he must have because the anecdote mentions the Emperor Antoninus.

Two singular things attract attention. The first is that Eudaemon's complaint is that, having been shipwrecked, he has been plundered, not by the inhospitable inhabitants of the shore, but by the tax gatherers, the publicans, the Farmers of the Revenue, the "Collectors" of those days.

The other, is that Eudaemon complains that he, having been shipwrecked in Italy, has been plundered by the publicans of the Cyclades. Now the Cyclades are not islands of Italy, but are in the midst of the Aegean Sea. What would they have to do with his shipwreck in Italy?

And, furthermore, why does Eudaemon petition the Emperor in the matter?

(Ist) The history of the various modes of dealing with shipwrecks and wrecked property among different nations and at different ages of the world, shows that in some cases, wrecked property was seized upon by the government of the country on whose shores it had been cast.

But we find in the Digests this provision on the subject,

"If at any time, a ship shall have been driven on the shore, or if at any time a ship shall be stranded, let.it belong to the owners. My treasury does not make interposition. For what right has the treasury in another's calamity, that gain to it should follow from so grievous a disaster?"

The authority for this law is stated in the Digests to be a Constitution attributed to the Emperor Constantine, who reigned about A.D. 300. But by some authorities it is attributed to Antoninus. If it was the law in Italy at the time of Eudaemon's disaster, the Italian publicans would not have plundered him. Pardessus tells us that there is some foundation for the opinion that among the Greeks a contrary provision prevailed, and that the treasury claimed that goods, thrown ashore as the result of a shipwreck, became the property of the government. If such was at any time the law among the Greeks or in the Cyclades, while in Italy the treasury left shipwrecked property to its owner, we can imagine how it was that Eudaemon's shipwrecked goods might not have been mölested by the Italian tax gatherers, and yet might have been pounced upon by Grecian publicans claiming to have rights under Grecian Law. 
(2nd) The question how came Eudaemon, who had been wrecked in Italy, to be plundered by publicans of the Cyclades, has presented itself to many writers. Selden, who in his Mare Clausum, discussed this whole anecdote at great length, quotes on this point from Samuel Petit, who says: "What a monstrous thing were here, that those who were shipwrecked in the sea upon the coast of Italy, should have been pillaged by publicans dwelling in the Cyclades Islands! What cosmographie is this? What relation have the publicans of those islands to Italy?" "Which," says Selden, "is most judiciously spoken."

Petit, in order to remove the difficulty, suggested that Eudaemon, instead of being shipwrecked "in Italy," had been wrecked "in the Telian," that is to say in the sea near the Island of Telos. And Selden says that he is quite willing to accept this change of the words. And many other suggestions have been made as to a possible error in the text where it reads that Eudaemon was wrecked in Italy, such as that it should have read in Attalia, or Icaria, or Aethalia, another name for Lemnos, or in the Tolian, of Mycalian, or Melian Sea.

But I venture to suggest that there is no necessity for any change of Eudaemon's story. And the explanation of the difficulty seems to me so simple that it is a marvel that it was overlooked. Eudaemon was a resident of Nicomedia, in Asia Minor, on the Propontis. And he might, quite possibly, when he sought to return home, after being wrecked in Italy, have committed himself, with the goods which he had saved, to a ship which carried hin as far on his homeward journey as some island of the Cyclacles. When the Apostle Paul was to go from Juclea to Rome, he embarked in a ship of Adramyttium, which was bound to places on the coasts of Asia, and having sailed in her as far as the City of Myra in Lycia, the centurion who had him in custody, found there a ship of Alexandria sailing for Italy, and he and his prisoner embarked in her.

Those were not yet the days of "regular liners;" and Eudaemon might very possibly have been able to get as far as the Cyclades with his goods, on his journey home to Nicomedia, when the tax gatherers there, learning that these goocls were shipwrecked goods, and being themselves familiar with the Greek law which forfeited such goods to the treasury of the State, pounced upon them as law ful prize, and doubtless charged Eudaemon with being engaged in defrauding the revenue. 
It is easy to fancy the indignation of Eudaemon and his determination to lay the case before the Emperor. We can read that indignation in the cleclaration of his petition, that he had been "plundered by the publicans."

(3rd) If the question was, therefore, whether that case was to be determined by the Greek Law or the Roman Law, and if the rights of the Imperial Treasury were involved, we can see why an appeal should have been made to the Emperor.

The reply of the Emperor, that the matter is to be decided: "according to the Rhodian Law, prescribed concerning nautical matters, so far as none of our laws is opposed," gives us no information whatever as to what was the Rhodian Law on this point, or any other. Strictly, the only conclusion to be drawn from it, is that there was a Rhodian Law relating to such a case as this, and possibly a Roman Law also. One old author says that Rhodes and the Cyclades were included in one political district, and that the Prefect of Rhodes was Prefect of the Cyclades. I have not been able to verify his statement, but, if it is correct, the reason for the mention of Rhodian Law is manifest.

In my opinion, therefore, all which can be gleaned from this story in the Digests as to the Rhodian Law of the sea is this:

(Ist) There was a Rhodian Law which Antoninus speaks of as "the Rhodian Law which is prescribed concerning maritime affairs." But whether that law had its source in wise customs of dealing, which by long use had crystalized into law, or whether it was the enunciation of just and clear-minded judges, or whether it was the construction of wise and far-seeing legislators-whether it was usage, decision or code, or partly of all, it is utterly impossible to tell. Antoninus might have spoken of it as he did, whichever it was.

(2nd) We have no anthentic information as to what any provision of Rhodian Maritime Laws was, except that one sentence stated by the Roman lawyer, Paulus, as the rule of law in cases of jettison, and stated by the authors of the Digests to havebeen a provision of that Rhodian Law.

The Digests have many other provisions on various subjects of maritime law, but, for them all, Roman, not Rhodian, authority is given. And whether there were any provisions of the Rhodian Law on those special subjects, and whether, if there were, they agreed or disagreed with the Roman Law, it is utterly im- 
possible to tell, for in every case the authors of the Digests have given the Roman Law with its Roman authority.

And ( 3 rd). Outside of that one sentence of the Digests and that work of Paulus from which that sentence was taken, we have no positive information, that the maritime law of Rome was indebted to Rhodes for any provision whatever.

But many eminent authors among whom I mention Selden in his Mare Clausum; Azuni in his Droit Maritime de l'Europe, and Kent in his Commentaries (Vol II, pp. 215, 5II), have stated apparently without hesitation, that the maritime law of Rhodes was adopted by Rome.

If these learned authors had recognized that fabrication-the so-called "Nautical Law of the Rhodians," as genuine and authoritative, they would have been justified in these statements; but each of them, except Selden, discards that "Nautical Law of the Rhodians" as having no authority whatever.

I cannot but think that all of these authors are subject to the criticism of not having "verified their references." I have been able to verify every reference which is brought in support of their statements, and many references which have been given by other authors who have made similar statements, ${ }^{2}$ and I will now bring together the actual facts which I have found bearing on this question of whether the Roman Maritime Law was substantially derived from the Rhodian Law, or not.

The earliest positive information which we have on this matter is the book of Paulus' Sentcnces, of which I have spoken. He lived about the year 200. The title of that chapter of his work of which I have spoken is Ad legem Rhodiam,-On the Rhodian Laze. In view of this, we may fairly concede that before the year A.D. 200, there existed a Rhodian Law, the subject of which was jettison. That chapter contains five articles, all of which are presumably sentences of Paulus on that Rhodian Law. The first of them is that well-known principle of law applicable to jettison.

The next piece of positive information is found in the action

1 See Godolphin, pp. 9, Io, I9; Molloy, Vol. I, p. xx; Strykins, De Collisione Navium, Sect. 3; Emerigon, Taité des Aparances, Preface, p. 2; L'Art de Verifier les Dates, Vol. III, p. 78; Valin, Preface, p. 2; Bonlay Patby, Vol. I, p. 37 ; Colquhoun, Summary of Roman Civil Law, Vol. III, p. 137; Robertson's Admiralty, p. 8; Amos, Roman Civil Law, p. 212; Ben. Ad., Sect. 179. 
of the authors of the Digests more than 300 years later, when they took that first article from Paulus and prefixed to it the statement, "It is provided by the Rhodian Law that," and inserted it in the Digests.

So we have the statement of the authors of the Digests that that one principle was a principle of Rhodian Law; and we have the fact that that one principle was, in A.D. 533, embodied in statute law by Justinian.

And, giving to the authority of Paulus the greatest weight possible, it may be conceded that that one principle had been imbedled in Roman Law for three hundred years before it was made statutory in the Digests. But it is a very long step from that single fact to the statement that Rome adopted the laws of the Rhodians, or that the Rhodian Laws were the foundation of the maritime law of Rome.

The next thing to be considered is that anecdote told by Volusitus Moecianus about Eudaemon's case. Moecianus told this story of Antoninus, who reigned from 138 to 162 A.D. Let us concede that Moecianus lived in the time of Antoninus. Let us assume that he had personal knowledge of the facts. And, as this story is embodied in the Digests formulated A.D. 533, we may reasonably concede from such an endorsement, even if it was given about 400 years after Moecianus told the story, that the story was true, and that Antoninus did say the words which Moeciantus related that he had said.

The only thing which it cottl be fairly claimed that the Emperor meant to say was "Let Eudaemon's case be judged by the nautical law of the Rhodlians." There was no call on the Emperor to say how any other case should be judged. And almost all the commentators so treat it. For instance, Pothier translates it, "Le $₹$ your matter (votre affaire) be juclged." (Pandectes T., 6 p. 19.)

Then we have the further statement at the close of the aneclote that the Emperor Augustus "has made the same decision."

We have then two decisions, one by Augustus, and one by Antoninus, that the question of the right of the treasury to shipwrecked property (for that was Eudaemon's case) should be decided by the nautical law of the Rhodians unless there was some Roman Law opposed. Whether there was or not, Antoninus plainly dicl not know. But. if there was any such Roman Law, he said that that must be paramount. This is altogether too slender 
an authority to support the statement that Rome adopted the Rhodian Maritime Law.

Putting these things together, we find that up to the time of the Digests, A.D. 533, Rome had adopted one principle of Rhodian Law, and had also said that, as to the title to shipwrecked property, if there was no Roman Law applicable, the Rhodian Law should be applied. And that is all that can be shown to have been done by Rome in that direction.

Now, as Rome was taken by the Goths in A.D. 409, any influence of Rhodian Law on Roman Law must have been before the date of the Digests.

And up to that time, we have no statement by any author, legal or other, that Rome had accepted anything of the Rhodian Law, except that one principle as to the law of jettison.

The question naturally arises, if this is so, how has it happened that such sweeping statements have been made by learned men, as to this wide indebtedness of Rome to Rhodes for her maritime law?

The Marquis de Pastoret whose dissertation on the Influence of the Rhodian Laws on Greece and Rome was published in 1748 , well said that "nothing is more common that to see modern authors repeat without examination the assertions of those who have preceded them in the sphere of jurisprudence and history." And here, I think, will be found the explanation of what has been so often said about the indebtedness of Rome to Rhodes for her maritine law. The falsity of that alleged Rhodian Law was not perceived till the learned Bynkershoeck tore to pieces its claims to authenticity in about the year 1709; and up to that time the writers on this subject, accepting its statements as true, had quite naturally thought that there was proof that the Rhodian Law had been adopted by various Roman Emperors. And, after its falsity was shown, writer after writer repeated the assertions of his predecessors, without stopping to examine how far those assertions must be modified, if the false document was to be excluded.

So Azuni says, "It is certainly true that Augustus solemnly recognized the Rhodian Law as that of Rome." And Kent makes the same statement. But, aside from that fabrication, there is no foundation for that statement, except the line in the Digests that Augustus decided the same thing which Antoninus decided. And Antoninus instead of having "solemnly recognized the Rhodian 
Law as that of Rome" had only said that one particular case was to be decided by Rhodian Law, if there was no Roman law opposed to it.

And, even if we were to take this as being a declaration of a general rule that all nautical cases should be decided by Rhodian Law unless the Roman Law was opposed, it would not give much assistance to this extravagant claim that Rhodian Law was the foundation of Roman maritime jurisprudence. For we know that there was a great body of Roman Law relating to maritime affairs. We have it preserved to us in the Digests with the Roman authorities assigned to it. While, as to what was Rhodian Law, we only know one principle. Nothing else that we know of the jurisprudence of Rome can be said to have been Rhodian Law; and, therefore, it cannot be asserted that Roman Law was indebted to Rhodian Law for anything else whatever.

Again, Kent also misstates that story of Antoninus. He says that Antoninus referred Eudaemon to the maritime laws of Rhodes "as being the laws which he said reere the sovereign of the sea." But Antoninus said no such thing. He said that law was the sovereign of the sea. He did not specify Rhodian Law or Roman Law as the law which, he said, ruled the sea, as he ruled the land. If there was any difference between them, it was not Rhodian Law, but Roman Law, which he declared to be sovereign.

The fact that that so-called "Nautical Law of the Rhodians" is a fabrication of an unknown date, is now universally recognized. And that being so, I do not hesitate to say, with all due deference to Azuni, Kent, and other learned authorities, that the statement that Rome was indebted to Rhode for her maritime law, outside of that one principle applicable to the case of jettison, is without solid foundation.

I see no reason why we are called tupon to look to any other sources than Roman sources for any provision which we find in the maritime law of Rome. The jurisconsults of Rome certainly showed themselves competent to deal with any questions which were presented to them by the increasing maritime commerce of Rome. Duobtless they examined the maritime laws of other maritime people, Phenicians, Carthaginians, Athenians, Rhodians, as we do the maritime laws of England, France and Germany, and came to their own conclusions. But why should it be saicl that Rome was indebted to Rhodes, any more than to any other 
maritime nation, for any part of her maritime law which cannot be directly traced to Rhodes? If a man were to find an old bottle in the ocean filled with water, and labelled "Water from the Hudson River," he would not be justified thereby in stating that the ocean drew its water from the Hudson River. And to my mind it is about as wide of the mark, to say that, because we find in the sea of Roman jurisprudence one principle, and one only, which bears upon it the label of Rhodes, therefore, Rome was indebted to Rhodes for her maritime law.

We can say that the principle on which the law as to jettison should rest, as the Rhodian law-giver, or jurisconsult, had stated it, so cmomended itself, to the jurisconsults of Rome, that it was taken bodily into Roman jurisprudence, with the label of Rhodes upon it. And this must be conceded to be a great honor. I have not made an exhaustive examination of the Digests on this point, but so far as $I$ have seen there is no other provision in all the fifty books of the Digests, which bears thus the name of another nation.

That one sentence has carried the name and fame of Rhodes down through seventeen centuries, and will carry it down the stream of future time till there shall be no more sea.

The Rhodian legislator or judge, who stated that principle so clearly, recognized that the difference between the land and the sea called for a different law to govern the sea. He saw that there must be a maritime law.

This Rhodian Law applied, to this case of misfortune and preservation from peril, a principle of justice and fair dealing which compelled appreciation and acceptance everywhere where it was known. If anyone has ever sought to introduce any opposing principle into the consideration of the multifarious mishaps of the ocean, or to extend the right of contribution among seafarers to any loss which did not have its origin where Rhodes had placed it, viz., in a sacrifice by one for the good of all, (like the author of the so-called Nautical Laze of the Rhodians, who proposed that if one passenger in a ship lost money overboard, all the other passengers should be compelled to help make it up), his effort has been useless and his work ephemeral.

That Rhodian principle has been the corner-stone upon which have rested through all the centuries, and still rest, the dealings of men of the sea with the innumerable cases of mishap which arise upon the sea. 
We must recognize the wisdom which led to the adoption of that principle into the jurisprudence of Rome. Aside from that, let us give to the jurisconsults of Rome the credit for the Maritime Law of Rome.

Robert D. Benedict, LL. D. 